удк: 331.215.24

DOI https://doi.org/10.32851/2708-0366/2021.7.12

Русс Д.A.

студентка,

Дніпровський національний університет імені Олеся Гончара

Кучеренко С.к.

кандидат економічних наук,

доцент кафредри економіки, підприємництва та управління підприємствами,

Дніпровський національний університет імені Олеся Гончара

Russ Daria, Kucherenko Sergiy

Oles Honchar Dnipro National University

\title{
КОНКУРЕНТОСПРОМОЖНІСТЬ ПРОДУКЦІЇ ПІДПРИЄМСТВА НА ВНУТРІШНЬОМУ РИНКУ
}

\section{COMPETITIVENESS OF PRODUCTS ENTERPRISED IN THE DOMESTIC MARKET}

Статтю присвячено дослідженню питання забезпечення конкурентоспроможності продукиії та підприємства у ияілому. Конкурентоспроможність нині виступає однією з провідних категорій економічної науки, з котрою традиційно асоиіюють успішність функціонування підприємств, стабільність й ефективність розвитку ринкової системи у иілому. На сучасному етапі глобального розвитку національної економіки напружується конкурентна боротьба між одногалузевими підприємствами. Це тісно пов'язується з інтеграцією України до міжнародного економічного простору, проникненням на державний ринок країни міцуних транснаціональних корпоращій. Саме ие знижує конкурентне лідерство українських підприємств у боротьбі за периість. Ось чому проблема підняття конкурентоспроможності продукиії та послуг національних підприємств на вищий рівень відіграє пріоритетну роль на сьогоднішньому етапі розвитку й $\epsilon$ надзвичайно важливою для зростання української економіки. Конкурентоспроможність сьогодні є найважливішим чинником досягнення комериійного успіху, щзо має вплив на конкурентоспроможність підприємства у цілому, тому кожна компанія прагне знайти иляхи ї̈ підвищення.

Ключові слова: конкурентоспроможність продукиї, підприємство, економіка, стратегія, методи оцінки, внутрішній ринок, конкурентна боротьба.

Статья посвящена исследованию вопроса обеспечения конкурентоспособности продукции и предприятия в цуелом. Конкурентоспособность выступпает одной из ведущих категорий сегодняшней экономической науки, с которой традиционно ассоциируют успешность функционирования предприятий конкурентных отношений, стабильность и эффективность развития рыночной системь в целом. На современном этапе глобального развития национальной экономики обостряется конкурентная борьба между одноотраслевыми предприятиями. Это тесно связано с интеграцией Украины в международное экономическое пространство, проникновением на государственный рынок страны крепких транснациональных корпораций. Именно это снижает конкурентное лидерство украинских предприятий в борьбе за первенство. Вот почему проблема повьшения конкурентоспособности продукции и услуг национальных предприятий на более высокий уровень играет приоритетную роль на сегодняшнем этапе развития и является первостепенно важной для роста украинской экономики. Конкурентоспособность сегодня является важнейшим фактором достижения коммерческого успеха и выступает важнейшим фактором, который влияет на конкурентоспособность предприятия в иеелом, поэтому каждая компания стремится найти пути ее повышения.

Ключевые слова: конкурентоспособность продукиии, экономика, стратегия, методы оценки, внутренний рынок, конкурентная борьба. 
The article is devoted to the study of the issue of ensuring the competitiveness of products and the enterprise as a whole. Competitiveness is one of the leading categories of today's economic science, with which the successful functioning of enterprises in competitive relations, stability and efficiency of the development of the market system as a whole are traditionally associated. At the present stage of the global development of the national economy, the competition between single-industry enterprises is intensifying. This is closely related to the integration of Ukraine into the international economic space, penetration of strong transnational corporations into the state market of the country. This is what reduces the competitive leadership of Ukrainian enterprises in the struggle for leadership. That is why the problem of raising the competitiveness of products and services of national enterprises to a higher level has a priority role at the current stage of development, and is of paramount importance for the growth of the Ukrainian economy. Competitiveness, today, is the most important factor in achieving commercial success and is the most important factor that affects the competitiveness of the enterprise as a whole, therefore each company seeks to find ways to improve it. At the present stage of global development of the national economy, competition between single-industry enterprises is intensifying. This is closely connected with the integration of Ukraine into the international economic space, the penetration of the state market of strong transnational corporations. This is what reduces the competitive leadership of Ukrainian enterprises in the struggle for supremacy. That is why the problem of raising the competitiveness of products and services of national enterprises to a higher level has a priority role at the current stage of development, and is of paramount importance for the growth of the Ukrainian economy. The issues of researching the competitiveness of enterprises are important and relevant both for the country's economy as a whole and for individual producers. In market conditions, high competitiveness of business entities is the key to obtaining high and stable profits. High competitiveness is the main condition for the development and operation of the enterprise.

Key words: competitiveness of products, economics, strategy, assessment methods, internal market, competition.

Постановка проблеми. Сьогодні конкурентний ринок зумовлений швидким зростанням споживчого попиту, а це свідчить про напруження конкуренції, посилення позицій конкурентів та скорочення часу запуску інноваційних технологій. Конкурентна боротьба змушує учасників ринку завжди контролювати дії власних суперників, приймати рішення, які долають негативні наслідки їх конкурентного тиску й сприяють постійному розвитку суб'єкта підприємництва в конкурентному середовищі, у тому числі контролюють його конкурентоспроможність.

Аналіз останніх досліджень і публікацій. Аналіз сенсу конкурентоспроможності підприємств та методів іiї визначення й шляхів підвищення відображено у працях багатьох відомих вітчизняних та закордонних науковців. Значна кількість та різноманітність публікацій свідчить про складність та серйозність цих питань. Головними дослідниками цієї теми є М.М. Галелюк, Т.Б. Харченко, О.Є. Кузьміна, Л.В. Балабанова, Г.С. Бондаренко. Учені намагалися максимально конкретизувати уявлення про управління конкурентоспроможністю у своїх роботах, а також визначити методологію дослідження її рівня на певних підприємствах.

Формулювання цілей статті. Метою статті є визначення поняття конкурентоспроможності, дослідження певних заходів і практичних указівок, націлених на підвищення рівня конкурентоспроможності продукції підприємства на внутрішньому ринку, пояснення їх потреби та значущості; розгляд методів оцінки рівня конкурентоспроможності продукції та шляхів їх вибору для гарантування всебічного зростання та розвитку підприємства; визначення заходів і практичних рекомендацій щодо підвищення конкурентоспроможності продукції підприємства.

Виклад основного матеріалу. Конкурентоспроможність можна визначити як динамічну характеристику товарів і послуг підприємства, що може трансформуватися залежно від ринків, часу та інших чинників. Продукти, які зазнали невдачі та були витіснені з ринку, можуть через деякий час стати успішними на даному ринку. Інакше кажучи, здобутий розвиток конкурентоспроможності підприємства у певний часовий проміжок не може бути розглянутий як довгострокова характеристика його 
ринкових аспектів окремо від ефективності. Але саме рівень конкурентоспроможності продукції підприємства напряму залежить від показника конкурентності, що зумовлює конкурентні переваги підприємства у цілому. Тому конкурентоспроможність не має універсального поняття і може бути використана лише для конкретних ринкових умов. Конкурентоспроможність зумовлюється конкурентними властивостями, які $є$ індивідуальними для кожного сектору ринку [8].

\begin{tabular}{|l|l|}
\hline \multicolumn{1}{|c|}{ Внутрішні } \\
\hline \multicolumn{1}{|c|}{ Конкурентні переваги } \\
- високий рівень організації управління; \\
- виробництво; \\
- маркетингова активність; \\
- фінансово-інвестиційна діяльність; \\
-інноваційно-технологічний розвиток; \\
- наявність сучасного обладнання \\
- науково-дослідна робота
\end{tabular}

Рис. 1. Складники внутрішніх та зовнішніх конкурентних переваг підприємства Джерело: складено за [2]

Під час аналізу конкурентоспроможності найважливішим є визначення типу конкурентних переваг (рис. 1), створених трьома групами факторів: відмінною якістю товару, що $є$ найголовнішою цінністю для споживачів; низькими витратами; ключовими «компетенція ми», що створюють особливу роль для покупців.

Відповідно до теорій та практик управління, гарантування виробництва продукції з високою конкурентоспроможністю виступає головною вимогою ринкової економіки. Конкурентоздатна продукція включає безліч параметрів, таких як: наявність торгової марки, супутніх послуг, органолептичні показники продукції, але головне - це якість продукції. Вона включає кілька параметрів: новизна, технічна підтримка, відсутність дефіциту, надійність [5].

Забезпечення стандартних якостей $є$ головним чинником збереження ринкових позицій та підтримки максимального обсягу продажів, відповідної стратегічної оцінки, розроблення політики розвитку підприємства. Аспект конкурентоспроможності продукції є одним із головних складників, який системно оцінює параметри продукції, котра може використовуватися на основі переходу компанії з цієї продукції на нові ринки [3]. Оцінка конкурентоспроможності товару - це визначення його рівня, що дає відновлений опис можливостей товару відповідати вимогам певного ринку в поточному періоді щодо продукції конкурентів. Класифікацію методів детальніше розглянуто в табл. 1. Оцінка рівня конкурентоспроможності передбачає дослідження ринку (опис та пропозиція, ринкові ціни, канали збуту), аналіз якості та кількох характеристик продукції, дослідження основних конкурентних властивостей товарів, економічних показників для визначення конкурентоспроможності та обробки зразків для порівняння.

Детальний аналіз методів надає можливість з'ясувати, що найбільшу увагу та практичну доцільність виявляють комплексний та змішаний, тому що вони забезпечують знаходження інтегрального показника [9]. Він важливий, оскільки дає змогу відстежувати динаміку змін конкурентоспроможності в часі та просторі. Окрім того, він закладає основи для розроблення відповідних управлінських рішень як основи для реалізації стратегії та тактики конкурентоспроможності [10]. 
Таблиця 1

Класифікація методів оцінювання конкурентоспроможності продукції

\begin{tabular}{|c|c|}
\hline Критерій & Види методів \\
\hline $\begin{array}{l}\text { За принципом, що } \\
\text { використовується }\end{array}$ & $\begin{array}{l}\text { - експериментальні (оцінювання окремих аспектів } \\
\text { конкурентоспроможності за певний момент часу є досить надійним, } \\
\text { але витратним із погляду часу); } \\
\text { - розрахункові (застосовують, якщо потрібно визначити груповий } \\
\text { параметр або загальний критерій); } \\
\text { - статистичні (застосовуються під час оцінювання } \\
\text { конкурентоспроможності на базі обсягів продажу); } \\
\text { - аналітичні (використовується для оцінювання групових критеріїв } \\
\text { та діяльності конкурентів); } \\
\text { - маркетингові (застосовуються для формулювання загального рівня } \\
\text { конкурентоспроможності) }\end{array}$ \\
\hline За номенклатурою & $\begin{array}{l}\text { - прямі (можуть містить достатню кількість критеріїв, серед } \\
\text { яких головними виступають якість і ціна, дають змогу визначити } \\
\text { інтегральний параметр якості або оцінювати відношення якості } \\
\text { до ціни); } \\
\text { - непрямі (головними також визначені якість та ціна, котрі закладені } \\
\text { в базу оцінювання після прямого розрахунку) }\end{array}$ \\
\hline $\begin{array}{l}\text { За стадіями } \\
\text { життєвого циклу }\end{array}$ & $\begin{array}{l}\text { - методи, що використовують загалом на стадії проєктування } \\
\text { та виробництва продукту; } \\
\text { - методи, які у цілому використовуються на стадії реалізації } \\
\text { та експлуатування продукції }\end{array}$ \\
\hline $\begin{array}{l}\text { За способом } \\
\text { відбору важливих } \\
\text { аспектів товару }\end{array}$ & $\begin{array}{l}\text { - відбір, який проводитимуть суб’єкти оцінювання; } \\
\text { - відбір має проводиться на основі експертного опису серед } \\
\text { внутрішніх та зовнішніх експертів; } \\
\text { - відбір грунтується на базі відповідей репрезентативної вибірки } \\
\text { покупців }\end{array}$ \\
\hline $\begin{array}{l}\text { За показниками } \\
\text { оцінки }\end{array}$ & $\begin{array}{l}\text { - диференційований; } \\
\text { - комплексний; } \\
\text { - змішаний }\end{array}$ \\
\hline $\begin{array}{l}\text { За формою } \\
\text { представлення } \\
\text { результатів }\end{array}$ & $\begin{array}{l}\text { - розрахунково-аналітичний; } \\
\text { - матричний метод (наприклад, «Матриця Нільсона»); } \\
\text { - графічний метод }\end{array}$ \\
\hline
\end{tabular}

Джерело: складено за [4]

Серед причин низької конкурентоспроможності продукції українських виробників є:

- низькі темпи науково-технічного прогресу;

- відсутність моральних та матеріальних стимулів для поліпшення якості продукції та розширення асортименту, модернізації виробничого апарату та впровадження нових технологій виробництва;

- моральний і фізичний знос основних фондів та використовуваних технологій;

- недостатній розвиток системи широкомасштабної безперервної підготовки фахівців 3 якості продукції, включаючи керівників підприємств, сучасна ідеологія управління якістю;

- у зв’язку з упровадженням гармонізованих з європейськими та міжнародними стандартами вимог;

- відсутність готовності багатьох підприємств до об'єктивно необхідного технічного переоснащення підприємств, розроблення сучасних технологій, нового випробувального обладнання, впровадження та сертифікації системи управління якістю, що вимагає значних коштів (інвестицій, позик тощо) та державної підтримки слаборозвиненого ринку, недостатня внутрішня конкуренція [1]. 
Таким чином, наявність проблеми підвищення конкурентоспроможності підприємства та продукції напряму залежить від ефективного розподілу власних і позичкових ресурсів в умовах конкурентного ринку. Проблематика підвищення рівня конкурентоспроможності та забезпечення гідних конкурентних переваг організацій у ринкових умовах завжди є однією з найактуальніших.

Процес керування рівнем конкурентоспроможності підприємства може бути представлений у вигляді взаємопов'язаних блоків:

- з'ясування головних пріоритетів (установлення цілей підприємств у сфері досягнення належного рівня конкурентоспроможності);

- постановка завдань (дослідження внутрішнього та зовнішнього середовища функціонування підприємства);

- постановка стратегії (створення альтернативних напрямів стратегії для досягнення ймовірного рівня конкурентоспроможності підприємства);

- втілення стратегії (вибір оптимального напряму стратегій та розроблення плану дій для досягнення бажаної конкурентоспроможності підприємства).

Управління конкурентною поведінкою бізнес-організації повинно грунтуватися на визначенні та ефективній реалізації збалансованої загальної конкурентної стратегії (табл. 2), яка зможе забезпечити конкурентну перевагу протягом тривалого періоду (5-10 років) [7].

Таблиця 2

Система конкурентних стратегій підприсмства

\begin{tabular}{|c|c|c|}
\hline \multicolumn{3}{|c|}{ Конкурентні стратегії підприємства } \\
\hline $\begin{array}{l}\text { Стратегії формування } \\
\text { конкурентних переваг }\end{array}$ & \begin{tabular}{|l|} 
Стратегія забезпечення \\
конкурентоспроможності підприємства
\end{tabular} & $\begin{array}{l}\text { Стратегії конкурентної } \\
\text { поведінки }\end{array}$ \\
\hline Контролю над витратами & \multirow{3}{*}{$\begin{array}{l}\text { - товарно-ринкова; } \\
\text { - ресурсно-ринкова; } \\
\text { - технологічна; } \\
\text { - соціальна; } \\
\text { - фінансово-інвестиційна; } \\
\text { - інтеграційна; } \\
\text { - управлінська }\end{array}$} & Наступальні \\
\hline Диференціації & & Оборонні \\
\hline Фокусування & & Коопераційні \\
\hline
\end{tabular}

Джерело: складено за [6]

Основні шляхи підвищення конкурентоспроможності включають:

- ретельне вивчення запитів споживачів та систематичний аналіз конкурентів;

- аргументована рекламна політика;

- створення нових продуктів;

- поліпшення якісної характеристики продукції;

- удосконалення обладнання;

- зниження загального рівня витрат;

- поліпшення обслуговування під час процесу купівлі та післяпродажного сервісу тощо [6].

Висновки. Для сучасних підприємців набуває актуальності проблема керування конкурентоспроможністю продукції підприємства, оскільки світова криза загострила складну ситуацію в конкуренції підприємств. За відсутності обгрунтованої та вчасної оцінки ступеня розвитку власного потенціалу конкурентоспроможності виявлення й дослідження чинників, що безпосередньо впливають на позицію підприємства серед конкурентів, його управлінська ланка унеможливлює розроблення та втілення стратегії продуктивного функціонування компанії.

Проводивши оцінку конкурентоспроможності суб'єкта господарювання, ви можете вирішити низку завдань: визначити рівень конкурентоспроможності в певний промі- 
жок часу, відстежити тенденції конкурентоспроможності за цей термін, визначити «вузькі місця» та потенціальні резерви для підвищення рівня конкурентоспроможності підприємства.

Управління конкурентоспроможною поведінкою бізнес-організації грунтується на розробленні та ефективному впровадженні збалансованої, адекватної конкурентної стратегії, що передбачає гарантування конкурентної першості протягом тривалого часу.

В умовах ринкової економіки конкурентна боротьба потребує від компанії безперебійного розвитку.

Головними напрямами підвищення рівня конкурентоспроможності є випуск нових видів товарів, зниження цін на товари та послуги, постійне залучення рекламних інструментів, реалізація продукції через збільшений перелік торгових посередників, запровадження інновацій. Управлінська верхівка підприємства має відстежувати зміни, що відбуваються в економічних умовах, та здійснювати різні перетворення в політиці виробництва та продажу товарів.

\section{Список використаних джерел:}

1. Верига Ю.А. Облік і звітність суб'єктів малого підприємництва : навчальний посібник. Київ, 2014. С. 44-48.

2. Гончар О.І., Галкіна Ю.Г Еволюція категорії «потенціал підприємства» та ії роль в економічних дослідженнях : навчальний посібник. Хмельницький, 2009. С. 132-140.

3. Іванов Ю.Б. Стратегія формування конкурентних переваг підприємства в умовах інтенсивної конкурентної боротьби : підручник. Київ, 2012. С. 68-72.

4. Кошелупов І.Ф. Система конкурентних стратегій підприємства. Вісник соиіально-економічних досліджень. 2013. № 36. С. 23-31.

5. Левицька А.О. Методи оцінки конкурентоспроможності підприємства: вітчизняні та закордонні підходи до класифікації. Механізм регулювання економіки : навчальний посібник. Київ, 2013. С. 41-48.

6. Павлова В.А., Кузьменко О.В. Конкурентоспроможність підприємства: управління, оцінка, стратегія : монографія. Дніпропетровськ, 2011. С. 213-220.

7. Фещур Р.В., Лебідь Т.В., Самуляк В.Ю. Методи оцінювання конкурентоспроможності підприємств. Науковий вісник Волинського національного університету імені Лесі Українки. 2010. № 4. С. 14-17.

8. Череп А.В. Економіка підприємства : підручник / за ред. А.В. Череп, В.В. Ярмош. Запоріжжя, 2014. С. 296-301.

9. Шинкаренко В.Г., Бондаренко А.С. Управление конкурентоспособностью предприятия : монография. Харьков : ХНАДУ, 2003. С. 94-98.

10. Яцковий Д.В. Сучасні методики оцінки конкурентоспроможності підприємства. Вісник соціально-економічних досліджень. 2013. Вип. 4(51). С. 111-117.

\section{References:}

1. Veriga Y.A. (2014) Oblik i zvitnist subiektiv maloho pidpryiemnytstva [Accounting and reporting of small businesses]. Kyiv (in Ukrainian)

2. Gonchar O.I., Galkina Y.G. (2009) Evoliutsiia katehorii "potentsial pidpryiemstva» ta yii rol v ekonomichnykh doslidzhenniakh [Evolution of the category "enterprise potential" and its role in economic research]. Khmelnytsky (in Ukrainian)

3. Ivanov Y.B. (2012) Stratehiia formuvannia konkurentnykh perevah pidpryiemstva v umovakh intensyvnoi konkurentnoi borotby [Strategy for the formation of competitive advantages of the enterprise in terms of intense competition]. Kyiv (in Ukrainian)

4. Koshelupov I.F. (2013) Systema konkurentnykh stratehii pidpryiemstva [The system of competitive strategies of the enterprise]. Bulletin of socio-economic research, no. 36, pp. 23-31.

5. Levitska A.A. (2013) Metody otsinky konkurentospromozhnosti pidpryiemstva: vitchyzniani ta zakordonni pidkhody do klasyfikatsii. Mekhanizm rehuliuvannia ekonomiky [Methods for assessing the competitiveness of the enterprise: domestic and foreign approaches to classification. The mechanism of economic regulation: textbook]. Kyiv. (in Ukrainian) 
6. Pavlova V.A. (2011) Konkurentospromozhnist pidpryiemstva: upravlinnia, otsinka, stratehiia: monohrafiia [Competitiveness of the enterprise: management, evaluation, strategy: monograph]. Dnipro (in Ukrainian)

7. Feshchur R.V., Lebid T.V., Samulyak V.Y. (2010) Metody otsiniuvannia konkurentospromozhnosti pidpryiemstv [Methods of assessing the competitiveness of enterprises]. Scientific Bulletin of Volyn National University named after Lesya Ukrainka, no. 4, pp. 14-17.

8. Skull A.V. (2014) Ekonomika pidpryiemstva [Business economics]. Zaporizhzhia (in Ukrainian)

9. Shinkarenko V.G. (2003) Upravlenye konkurentosposobnostiu predpryiatyia [Management of enterprise competitiveness]. Kharkiv: KhNADU. (in Ukrainian)

10. Yatskovy D.V. (2013) Suchasni metodyky otsinky konkurentospromozhnosti [Modern methods of assessing the competitiveness of the enterprise]. Bulletin of socio-economic research, vol. 4, no. 51, pp. 111-117. 